\title{
Geological Survey of India - The premier Earth science organization of India
}

Geological Survey of India (GSI) is an attached department to the Ministry of Mines, Government of India and is engaged in collection of basic earth science data through its 33 pan Indian establishments. It employs about 2900 scientific professionals and disseminates the acquired knowledge to the government, industry and general public.

\section{Background}

GSI was established in 1851 by the East India Company "to study and explore availability of coals in the eastern parts of India for powering steam transport". Sir Thomas Oldham, the first Director of GSI, broadened the scope of GSI's work to include geological mapping, mineral exploration and basic geoscience research. A major achievement during the pre-independence era was the publication of the first geological map of India and adjoining countries in 1877 . The discovery of iron ore deposits in the Chhota Nagpur Plateau in 1906 heralded the industrial revolution in India. For almost hundred years since its inception, GSI was manned mainly by the British geologists and the seminal contributions during this period include (i) publications of Memoirs on geology of Himalaya, Rajasthan, Cuddapah, Singhbhum and Gangpur regions; (ii) discoveries of iron and manganese ores in central India, copper belt in Eastern India, mica fields of Bihar and many other world class mineral deposits; (iii) studies on Siwalik mammals and development of concept of Gondwanaland, (iv) classic studies on Great Cachar $\left(10^{\text {th }}\right.$ January, 1869), Kangra (1905) and Bihar-Nepal (1934) earthquakes and (v) development of the layered theory of the interior of the earth. In the post-independence era, GSI played a pivotal role in fulfilling the aspirations of a developing nation that necessitated establishment of need-based geoscientific organizations and carved institutions like Indian Bureau of Mines, Oil and Natural Gas Commission, Atomic Minerals Division, Central Ground Water Board, Mineral Exploration Corporation and Coal India Limited from its own niche. However, GSI continued its core activities and after liberalisation of India's National Mineral Policy in 1993 and 2008, the robust geological mapping and mineral exploration database generated by the GSI over the years has been found very useful for taking investment decisions by the private entrepreneurs.

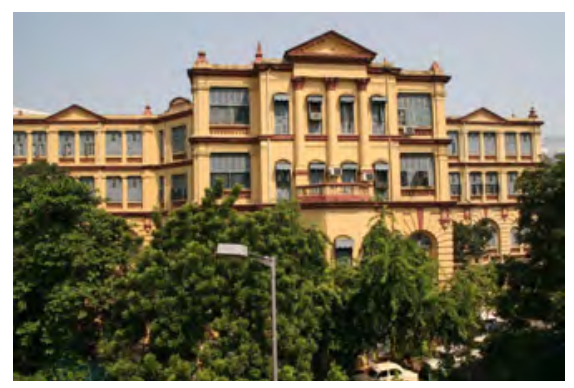

First GSI office complex at Kolkata

Core activities and significant results

Currently, GSI conducts its core activities through five functional missions.

Mission I: Baseline geoscience data generation. Mapping programmes under- taken includes (i) Systematic Geological Mapping - 3.09 million sq. $\mathrm{km}$ area on 1:50,000/63,360 scale mapped; (ii) Specialized Thematic Mapping - mainly to aid fundamental and applied geosciences programmes; (iii) Marine and Coastal Survey Mapping-covered 2.015 million sq $\mathrm{km}$ of EEZ and Territorial Waters of India (Ocean Going Research Vessel is in final phase of induction); (iv) Multisensor Airborne Survey - covered 0.5 million line $\mathrm{km}$ over an area of 0.29 million sq. km; (v) Geomorphological Mapping - achieved under Natural Resource Census programme, (vi) Hyperspectral Mapping, and (viii) National Geochemical mapping.

Mission II: Mineral exploration. This mission monitor programmes pertaining to new mineral search and the projects taken up to augment the existing mineral resources. In

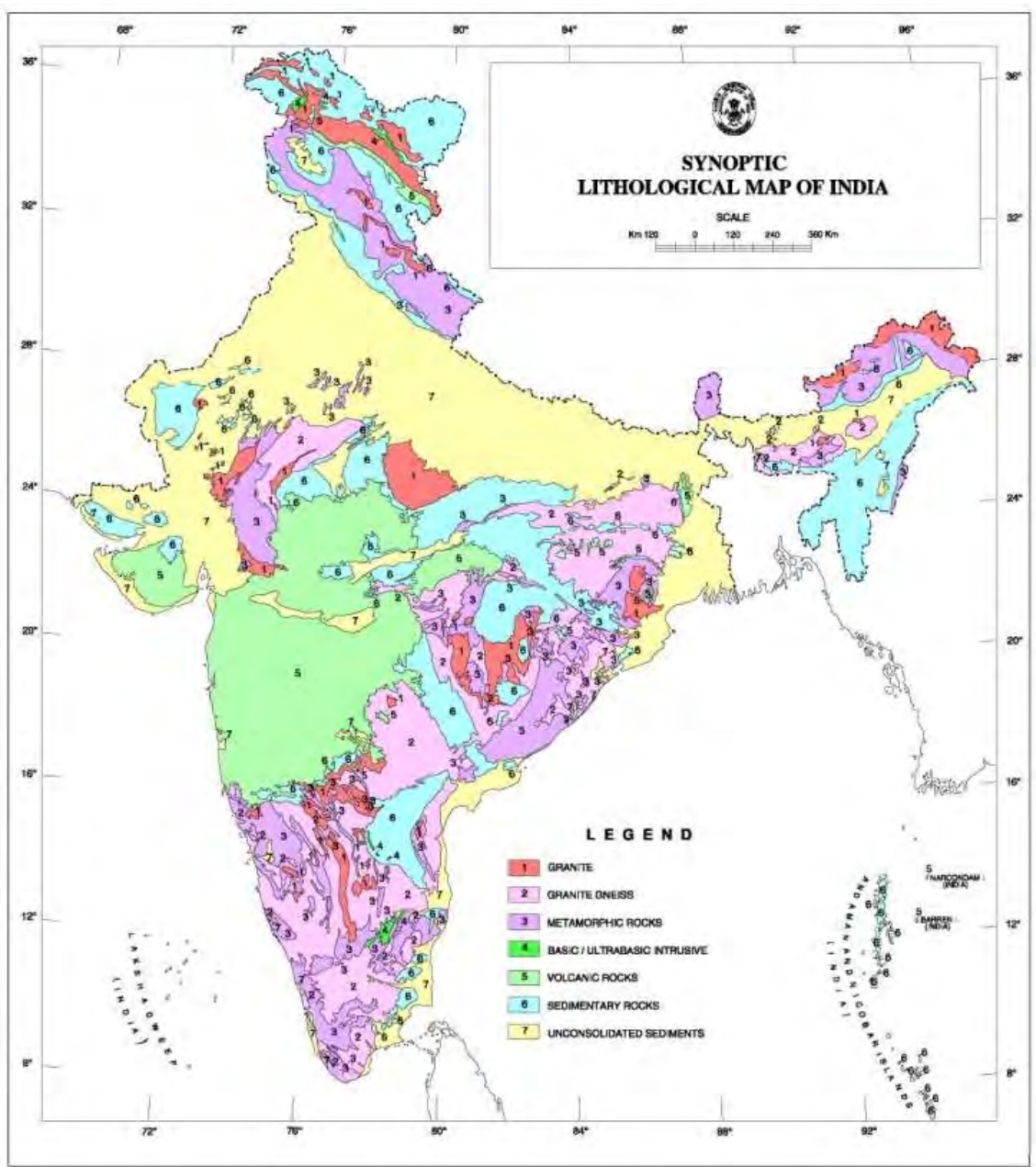

Lithological map of India 

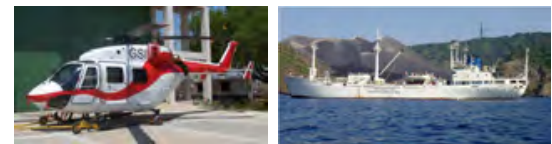

GSI's helicopter and ship for aerial and marine surveys.

post-independence period GSI is credited with spectacular discoveries of bauxite, coal, lignite, copper, manganese, chromite, gold, lead, zinc, PGE and coal bed methane. GSI has also identified 340 hot springs from different parts of the country (geothermal resource potential of 10,600 MW has been estimated).

Mission-III. Geoinformatics and geoscience data. It is responsible for acquiring, storing, and analysing geoscience data and information. In response to the increasing public demand for relevant geoscience information, together with its statuary task of supporting government and local authorities in sustainable resource development, environmental protection, and land-use planning and to ensure its compatibility with National Natural Resources Management System, GSI has developed Spatial Data Warehouse, Metadata catalogue, Map Server and a Net-Portal (www.portal.gsi.gov.in). Map production unit prints thematic maps in GIS platform and the Publication unit disseminates the newly acquired data from all the missions. GSI's Central Library, established in 1856, houses the richest collection of geoscientific literature in India. Currently it holds in its archive more than 700,000 publications including 600 geological and related journal titles. The archival collection of books in English and other languages dating back to as early as $16^{\text {th }}$ century are some of the rare repository of geoscientific literature.

Mission-IV. Fundamental and applied geosciences programmes handles projects related to the seismic and geo-environmental hazard assessment and their mitigations (GSI has published the Seismo-tectonic Atlas of India), geodynamic studies, seismic tomography studies, landslide studies, geotechnical studies to the civil engineers, polar studies, (through research stations 'Dakshin Gangotri', 'Maitri' and 'Bharti' in Antarctica and 'Hemadri' at Svalbard in Arctic region), planetary Studies (over 600 diverse types of chondrites, achondrites and iron meteorites, fell or found, within Indian Territory), glacier studies (a detailed inventory of 9575 Himalayan glaciers has been brought out in published form), paleoclimatic studies (through the programmes on coastal regions, glaciology, Himalayan cryosphere, desert geology, and carbon sequestration and Quaternary chronostratigraphy studies (in India as well as ice core studies from Antarctica). The other significant programmes of GSI include studies on Coastal Wave Dynamics in east coast, Thar Desert, elemental contamination and toxicity in groundwater, EIA of urban industrial growth centers, domestic/ hospital/ industrial/ nuclear waste disposal, trace-element hazard from fly-ash in coal-based thermal power plants, identification and maintenance of National Geological Monuments and conservation of archaeological monuments of world heritage sites. Maintenance of Repository of Index fossil for Research (includes unique collection of about 250,000 fossils representing the entire spectrum of geological time scale of the Indian subcontinent, accumulated over 160 years).

Mission-V. Training and capacity building. It has several specialized training centers situated in different geological terrains so that the subject-specific field training can be provided with ease. This is the only Institute of its kind in the country where emphasis is given to extensive field demonstrations backed by sound conceptual learning. The training policy of the department envisages (a) induction level training of about one year duration (b) periodic in-service training for the young professionals (c) refresher and advance training programmes for middle/higher level geoscientists and (d) courses on scientific, administrative and management needs. The courses offered include geological, geochemical and geophysical mapping, mineral exploration, airborne and marine surveys, remote sensing, active fault studies, earthquakes and seismic microzonation, geo-informatics for natural hazard studies including risk management, geotechnical investigations, GIS and information technology, management courses and customized courses on client's needs.

\section{Vision for future work}

GSI continues to contribute to the nation building by way of providing accurate geoscientific information to policy makers so that it forms part of the government effort that addresses vital issues of food and energy securities to its burgeoning population and also to evolve mitigation mechanisms to shield the life and property from ever- devastating natural hazards. The future visions for the GSI enshrined in its Charter include:

- To simulate the economic development by adhering to long term policies that aim at improving the quality of life in the country

- To create a close-knit national geoscientific community through leadership and collaborative partnership that can take up greater challenges in future.

- To promote and prioritize research in the field of fundamental and applied geosciences.

The unprecedented population growth during last few decades and its likely continuance during next few decades have direct consequence for increase need for natural resources. This has also caused greater stress on geological surveys across the world. There is global concern for urgent need to understand the complex interaction of physical, biological and chemical phenomena that regulate the processes on the planet earth, their symbiosis with humans and problems of increasing water, energy and food scarcity and rapidly depleting natural resources. GSI as the premier earth-science organization of the second most populous country is eager to work with the world geo-community to address these issues.

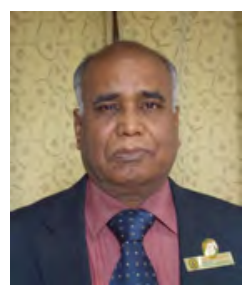

A. Sundermoorthy, Director General, GSI has a long technical and a d m i n is trative experience in GSI that includes extensive geological mapping in Precambrian rocks of southern India and Tertiary rocks of northeastern parts of India. He has led multidisciplinary geoscientific projects that helped in identification of significant resources of molybdenum, base metals, lignite and gold in Tamil Nadu and coal in Gondwana basins of eastern India. He prepared a comprehensive XII five year plan document for GSI that outlines thrust areas for mineral exploration, implemented GSI's modernization programmes and adopted proactive role with all the stakeholders in the field of geosciences in forging geoscience partnerships with state geological institutions and central government organizations, academic institutions and geological surveys of other nations for knowledge sharing in specific domains and for collaborative research programmes. 